\title{
PЕЦЕНЗІЯ НA: KOLODA V., GORBANENKO S. AGRICULTURE IN THE FOREST STEPPE REGION OF KHAZARIA. LEIDEN - BOSTON: BRILL, 2020. 116 P.
}

\author{
Олег Бубенок
}

проф., д-р. і. наук, Інститут сходознавства ім. А. Кримського

Національної академії наук України, 01001, м. Київ, вул. М. Грушевського, 4, helgebub@i.ua, https://orcid.org/0000-0002-0104-6081

\section{REVIEW OF THE MONOGRAPH: KOLODA V., GORBANENKO S. AGRICULTURE IN THE FOREST STEPPE REGION OF KHAZARIA. LEIDEN - BOSTON: BRILL, 2020. 116 P.}

\author{
Oleg Bubenok \\ Prof., Dr.h.Sc., A. Krymskyi Institute of Oriental Studies 01001, Kyiv, st. Hrushevsky, 4, \\ helgebub@i.ua,https://orcid.org/0000-0002-0104-6081
}

Останнім часом для дослідників історії Хозарського каганату сталася знаменна подія - вийшла англомовна версія монографії В. Колоди та С. Горбаненко «Сільське господарство населення Хозарського каганату в лісостеповій зоні» ${ }^{*}$. Це може свідчити про зростання інтересу світової наукової громадськості до хозарознавчих студій. Отже, В. В. Колода та С. А. Горбаненко гідно репрезентували свої дослідження на міжнародному рівні. Це значний успіх. Тому приємно привітати авторів із цим досягненням.

Актуальність теми дослідження обумовлена тим фактом, що в останні післярадянські десятиліття виходило не так вже багато узагальнюючих монографічних досліджень, безпосередньо присвячених населенню північно-західних територій Хозарського каганату. Як справедливо зазначили у Вступі автори, в Україні такою роботою була монографія О. О. Тортіки «Північно-Західна Хозарія в контексті історії Східної Європи (друга половина VII - третя чверть X ст.)». Ця робота була написана як суто історичне дослідження із залученням археологічних матеріалів. Проте ще не було в останні десятиліття узагальнюючого археологічного дослідження, присвяченого пам'яткам лісостепового варіанту салтівської культури. Білою плямою для дослідників залишалася сільськогосподарська діяльність носіїв салтівської культури в субрегіоні. Тому вихід монографії В. В. Колоди та С. А. Горбаненко «Agriculture in the Forest Steppe Region of Khazaria»є дуже вчасним.

Можна повністю погодитись 3 думкою авторів монографії, що сільське господарство становило основу економіки Хозарського каганату як й інших ранньосередньовічних держав Європи та Азії. Раніш В. К. Міхєєв опублікував монографію, присвячену господарству салтівського населення в басейні Дону та Сіверського Дінця. Але час вимагає окремого монографічного дослідження, присвяченого дослідженню саме сільського господарства племен лісостепу у складі Хозарського каганату. Це і становить актуальність теми

\footnotetext{
* Перше видання монографії вийшло українською мовою в 2018 р.: Колода В. В., Горбаненко С. А. Сільське господарство населення Хозарського каганату в лісостеповій зоні. Київ: Академперіодика, 2018. $170 \mathrm{c}$.
} 
дослідження. I автори дослідження намагалися заповнити цю прогалину наших знань про Хозарський каганат.

Варто зазначити, що автори монографії є відомими фахівцями в галузі хозарської археології. Особливо це стосується В. В. Колоди, який досліджує пам'ятки салтівської культури протягом більше трьох десятиліть. Він $є$ автором кількох монографій та не однієї сотні статей, присвячених вивченню пам'яток салтівської культури в лісостепу. Його ім'я широко відоме у науковому світі далеко поза межами України. Він достойно представляє харківську школу хозарознавства.

Другий автор книги С. А. Горбаненко представляє Відділ археології ранніх слов’ян Інституту археології НАН України. Сфера його наукових інтересів: сільське господарство і промисли людських спільнот на теренах Лівобережної України до утворення Київської Русі. Але він фахівець із дуже специфічної галузі - палеоботаніки, що має пряме відношення до дослідження розвитку сільського господарства. Про це можуть свідчити його чисельні публікації в Україні та поза ії межами, присвячені сільському господарству слов'ян та їхніх сусідів в період раннього Середньовіччя.

Отже, авторами монографії «Agriculture in the Forest Steppe Region of Khazaria» $\epsilon$ дуже досвідченні дослідники і їхня компетентність не підлягає сумніву. Тому автори монографії продемонстрували високій професіоналізм у висвітленні такого питання, як сільське господарство у лісостеповій зоні Хозарського каганату. Варто надати належне авторам дослідження за те, що вони не намагалися дати якусь етнічну атрибуцію пам'яткам салтівської культури, бо це питання дуже складне. Як відомо, на початку XX ст. перші дослідники Верхньосалтівського комплекса пов'язали місцеві пам'ятки, представлені катакомбами, безпосередньо з хозарами (Babenko 1910; Babenko 1914; Pokrovskiy 1905). Трохи згодом А. А. Спіцину вдалося довести, що катакомбні могильники салтівського типу знаходять прямі аналогії на Північному Кавказі, саме там, де письмові джерела середньовіччя традиційно локалізують аланів (Spizhin 1909). Крім того, В. К. Міхєєву в лісостеповій зоні серед пам'яток салтівської культури вдалося виявити трупоспалення, етнічна приналежність яких до сих пір є предметом дискусій (Mikheev 1974). Bapто також згадати грунтові могильники салтівської культури в лісостепу, які традиційно пов’язують 3 протоболгарами. Останнім часом дослідники схиляються до думки, що вже не можна називати лісостеповий варіант салтівської культури «аланським». Як бачимо, до їхнього числа належать також і автори монографії «Agriculture in the Forest Steppe Region of Khazaria».

Монографія має чітко продуману структуру і складається із Вступу, шести розділів, списку літератури, додатків, тощо. У Вступі обгрунтована актуальність теми та поставлені мета і завдання дослідження.

Мета дослідження - це уведення до наукового обігу нових даних на тлі максимально повної добірки інформації з басейну Сіверського Дінця та розширений аналіз із залученням доступних даних і методів природничих наук. Відповідно до цього окреслені завдання дослідження: а) огляд історії археологічних досліджень салтівських пам'яток субрегіону; б) опис використаних методів; в) створення по можливості повного опису довкілля як одного з найголовніших чинників у визначенні сільськогосподарських тенденцій субрегіону; г) аналіз сільськогосподарських занять носіїв салтівської культури відповідно до основних галузей: землеробства та тваринництва; д) порівняння стану сільського господарства населення Хозарського каганату і сусіднього слов'янського населення. Відповідно до поставлених завдань і побудована структура монографії.

Так, в першому розділі «Historiography and History of Research» йдеться про дослідження пам'яток салтівської культури у лісостеповій зоні в басейні Дону і Сіверського Дінця. Авторами подано практично усю можливу інформацію по цій темі. Тут згадані імена таких дослідників, як М. І. Артамонов, В. К. Міхеєв, М. О. Макаренко, В. О. Бабенко, С. А. Семенов-Зусер, Д. Т. Березовець, Б. А. Шрамко, С. О. Плетньова, А. З. Вінніков, Г. Є. Афанасьєв, В. В. Колода, Г. Є. Свистун, В. І. Квітковський, Н. В. Чернігова, Ю. Г. Чендєв, Р. В. Кройтор, С. А. Горбаненко. Але на цьому список дослідників лісостепового варіанту салтівської культури не можна вважати вичерпаним. У розділі окремо наведено історію досліджень найбільш важливих пам'яток салтівської культури, розташованих біля однойменних поселень у субрегіоні: Верхній Салтів, П'ятницьке I, Мохнач, Коропові 
Хутори, тощо. Саме матеріал із цих ранньосередньовічних поселень і став основою для досліджень авторів монографії.

Другий розділ «Methods of Interpreting the Agricultural Material» найбільш важливий в монографії, бо свідчить про суто науковий підхід авторів до вирішення проблеми. Так, автори виділяють в інтерпретації сільськогосподарського матеріалу два чинники: антропогенний та природний. До першого вони схильні відносити знаряддя для землеробства та тваринництва. Але сільське господарство, як справедливо зазначають автори монографії, можливе лише при взаємодії обох чинників. Отже, це закономірно привело дослідників до використання методів не лише гуманітарних, а й природничих наук. В розділі у великому обсязі представлені реконструкції сільськогосподарських знарядь праці салтівців, що стало можливим завдяки використанню археологічного матеріалу. Але важливим стало широке використання палеоботанічного матеріалу. I це закономірно, бо один із авторів монографії С. А. Горбаненко відомий фахівець саме в палеоботаниці. Такий підхід дозволив встановити які сільгоспкультури і як вирощували салтівці. Що стосується вивчення тваринництва, то у дослідженні були використані методи археозоології. У цьому розділі автори зробили цікаве спостереження, згідно з яким співвідношення видів у стаді і видів зернових частково дає змогу встановити підпорядкованість потреб однієї галузі сільського господарства потребам іншої.

Третій розділ «Natural Conditions and Resettlement Areas» присвячено аналізові природних умов, що існували у лісостепу більше тисячі років тому. Необхідність цього розділу автори монографії пояснюють тим, що економіка давніх суспільств, особливо сільське господарство в його традиційних формах, значною мірою залежало від природно-кліматичних умов і особливостей природного ландшафту в місцях створення поселень. Такий підхід варто вважати досить коректним. У результаті, автори прийшли до дуже важливого висновку, що землеробське населення потенційно могло населяти переважну частину досліджуваної території та використовувати ії для ведення сільського господарства. Необхідно також підтримати ідею авторів, що у X-XI ст. в Європі та на інших континентах відбувалось найбільше потепління. Це повністю узгоджується 3 даними письмових джерел. Варто згадати, що у X ст. виникла назва острова на Півночі: Грінланд - «Зелена країна», тобто сучасна Гренладія.

Четвертий розділ «Arable Farming» можна вважати центральним, бо його присвячено основному заняттю салтівського населення лісостепової зони - землеробству. Автори монографії вирішили провести комплексний аналіз землеробства, враховуючи знаряддя праці, природні умови і палеоботанічний матеріал на детально досліджених салтівських пам'ятках лісостепу. Використання археологічного матеріалу дозволило авторам дійти до висновку, що основним знаряддям для обробки верхнього шару землі з використанням тяглової сили тварин було рало як з металевими частинами, так і суцільно дерев'яне. Були виявлені й інші землеробські знаряддя: мотики та лопати. Дуже важливе значення мають палеоботанічні дані, які свідчать, що салтівці вирощували наступні культури: просо, ячмінь плівчастий, жито, горох, овес, тощо. Вдалося також виділити і знаряддя для збирання врожаю: серпи, коси, тощо. Про зберігання врожаю можуть свідчити зернові ями, глиняний посуд, тощо. Це дає підстави вважати, що відомі на території України наземні кошниці для зберігання зерна або їхній північнокавказький аналог - сапетки ще не були відомі салтівському населенню. Для переробки врожаю носії салтівської культури використовували зернотерки і жорна, де останні суттєво переважають. Це важливе спостереження, що може свідчити про високий рівень аграрного господарства. Але не зрозуміло, за рахунок якої енергії приводилися в дію ці жорна. Загалом, автори монографії переконливо показали, що у салтівців зернове землеробство переважало над іншими видами діяльності.

П’ятий розділ «Animal Husbandry» присвячено розвитку тваринництва у осілого населення хозарського лісостепу. Дослідникам вдалося встановити, яких тварин розводили салтівці. Це - велика рогата худоба, кози та вівці, коні, свині, тощо. Про тваринництво можуть свідчити не лише кістки згаданих тварин, а й спеціальні знаряддя праці - різницькі ножі, кінське спорядження, ножиці для підстригання дрібної рогатої худоби, тощо. Важливе значення має головний висновок - населення лісостепу впроваджувало комплексне землеробсько-тваринницьке господарство, що передбачало осілий спосіб життя. 
Але у даному випадку хотілось би поправити авторів і запропонувати термін «твариницько-землеробське господарство», бо у попередньому розділі вони довели, що у салтівців землеробство переважало над тваринництвом. Цікаво, що серед тварин були зафіксовані віслюки та верблюди як нетутешні рідкісні тварини, які прибули сюди з караванами купців. На жаль, не зазначено види верблюдів: верблюд одногорбий - Camelus dromedarius або верблюд двогорбий - Camelus baktrianus.

Шостий розділ «The Khazars and their Neighbors: a Comparative Analysis, in Lieu of Conclusions» $є$ заключним. У ньому порівнюється господарство носіїв салтівської культури у лісостепу з господарством сусідніх слов'янських племен. У результаті автори монографії прийшли до висновку, що існували спільні і відмінні риси. Спільні риси проявлялися в тому, що існував високий рівень розвитку технічної бази землеробства, схожа техніка ведення землеробства, тощо. Схожість в аграрній діяльності автори монографії пояснюють контактами та взаємовпливами слов'ян і салтівців. Що стосується відмінностей, то це знаряддя для збирання врожаю, які виключно у салтівській культурі представлені збірними формами, а серед слов'янських матеріалів такі знахідки досі не відомі. Відносно тваринництва автори дослідження відзначили, що у цих груп населення такий вид господарства розвивався повністю самостійно.

Проте у монографії є положення, які потребують принаймні додаткового пояснення. Це вже стосується самої назви англомовного варіанту книги - «Agriculture in the ForestSteppe Region of Khazaria». Тоді як україномовний варіант книги мав назву - «Сільське господарство населення Хозарського каганату в лісостеповій зоні». Питання до перекладача: чому «Khazaria», а не «Khazar Kaganate»?

На думку сучасних дослідників, територію Хозарського каганату VIII-X ст. можна розділити на два регіони, що мали особливий адміністративний та політичний статуси: 1) власне Хозарія - землі Дагестану та Нижньої Волги, що належали безпосередньо хозарській верхівці та кочовим племенам, які злилися з хозарами; 2) території, населені народами, які були васалами щодо хозарського кагана (Gadlo 1979; Novoselzhev 1990). Тобто iз англомовного варіанта слідує, що монографію присвячено заняттям населення, яке проживало у степах Волго-Доння.

Окрім того, в історіографічній частині монографії, де йдеться про історію досліджень Верхнього Салтова, немає жодного слова про довготривалі експедиції Харківського історичного музею. У вісімдесяті роки ХХ ст. їх очолював В. Г. Бородулін, а після 1991 р. В. С. Аксьонов. Питання до авторів монографії: чому про це немає інформації?

Варто зазначити, що в основному тексті монографії згадуються імена цих дослідників. А в списку використаної літератури монографії згадано кілька публікацій В. С. Аксьонова, присвячених дослідженню Верхнього Салтова. Сам автор цієї рецензії брав участь у роботі Верхньосалтівської археологічної експедиції XIM з 1989 по 1991 рр., яку очолював тоді В. Г. Бородулін. Наслідком цього стала публікація статті у журналі «Археологія», цілком побудовану на звітах В. Г. Бородуліна (Bubenok 1993).

Однак все це не знижує високого наукового рівня монографії В. В. Колоди та С. А. Горбаненка. Ця робота $є$ вагомим внеском у розвиток салтівської археології. Не сумніваюся в тому, що дослідження викличе великий інтерес не лише серед фахівців-археологів, а й серед істориків, етнологів, представників сільськогосподарських наук, тощо. Монографію доцільно було б використовувати як для написання наукових праць, так і для підготовки університетських спецкурсів. Загалом, дослідження справляє дуже позитивне враження.

\section{ЛITEPATУPA / REFERENCES}

Babenko, V. A. 1910. Novyie sistematicheskie issledovaniya Verhne-Saltovskogo katakombnogo mogilnika 1908 goda. Moskva. (In Russian).

Бабенко, В. А. 1910. Новые систематические исследования Верхне-Салтовского катакомбного могильника 1908 года. Москва. s. $21-42$.

Babenko V. A. 1914. Pamyatniki hazarskoy kulturyi na yuge Rossii. Trudyi XV AS. T. I. Moskva,

Бабенко, В. А. 1914. Памятники хазарской культуры на юге России. Труды $X V A C$. Т. І. Москва, c. $21-42$. 
Bubenok O. B. 1993. EtnIchna nalezhnIs yamnih pohovan VerhnosaltIvskogo mogilnika. Arheologiya, No. 4, s. 49-58. (In Russian).

Бубенок, О. Б. 1993. Етнічна належнісь ямних поховань Верхньосалтівського могильника. Археологія, № 4, c. 49-58.

Gadlo A. V. 1979. Etnicheskaya istoriya Severnogo Kavkaza IV-X vv. Leningrad: LGU, s. 27. (In Russian).

Гадло, А. В. 1979. Этническая история Северного Кавказа IV-Х вв. Ленинград: ЛГУ, с. 27.

Miheev V. K. 1985. Podone v sostave Hazarskogo kaganata. Harkov: HGU. 146 s. (In Russian).

Михеев, В. К. Подонье в составе Хазарского каганата. Харьков: ХГУ. 146 с.

Miheev V. K., Degtyar A. K. 1974. Raskopki Suhogomolshanskogo kompleksa. AO. 1973. Moskva: Nauka, s. 309. (In Russian).

Михеев, В. К., Дегтярь, А. К. 1974. Раскопки Сухогомольшанского комплекса. АО. 1973. Москва: Наука, с. 309.

Novoseltsev A. P. 1990. Hazarskoe gosudarstvo i ego rol v istorii Vostochnoy Evropyi i Kavkaza. Moskva: Nauka, s. 143. (In Russian).

Новосельцев, А. П. 1990. Хазарское государство и его роль в истории Восточной Европы и Кавказа. Москва: Наука, с. 143.

Pokrovskiy A. M. 1905. Verhnesaltovskiy mogilnik. Dnevnik raskopok. Tr. XII AS. Harkov, s. 460 490. (In Russian).

Покровский, А. М. 1905. Верхнесалтовский могильник. Дневник раскопок. Tp. XII AC. Харьков, c. $460-490$.

Spitsyin A. A. 1909. Istoriko-arheologicheskie razyiskaniya. Iskonnyie obitateli Dona i Dontsa. ZhMNP. Novaya seriya. Ch. XIX, s. 60-80. (In Russian).

Спицын, А. А. 1909. Историко-археологические разыскания. Исконные обитатели Дона и Донца. ЖМНП. Новая серия. Ч. ХІХ, с. 60-80.

Tortika A. A. 2006. Severo-Zapadnaya Hazariya v kontekste istorii Vostochnoy Evropyi (vtoraya polovina VII - tretya chetvert H vv.). Harkov: HGAK. 555 s. (In Russian).

Тортика, А. А. 2006. Северо-Западная Хазария в контексте истории Восточной Европы (вторая половина VII - третья четверть Х вв.). Харьков: ХГАК. 555 с.

Дата подання статті до редакції - 12 січня 2021 p. 